\title{
Textual Repetition as a Manifestation of Irony
}

\author{
Manana Dalalyan \\ Yerevan State University
}

\begin{abstract}
Text is a unit of language in use. It is a lexico-grammatical unit realized through a phonological system with its own hierarchy of units (Halliday 1977:6-7). Text has been defined as a communicative occurrence which meets seven standards of textuality cohesion, coherence, intentionality, acceptability, informativity, situationality and intertextuality (Halliday, Hassan 1976:14-18). Application of repetition is also an important characteristic of a text. This particular study gives us a wide diapason to ascertain that repetitions on text level used by O. Wilde imply shades of comical meaning in general and ironical meaning in particular. The methodology underlies in the notion of irony asserted in the study of modality worked out by V. Vinogradov. The linguist suggests that there are two types of modality - objective and subjective. Objective modality mainly presupposes the author's explicit evaluation of the surrounding world and events, thus revealing shades of humor. In the case of irony the utterance is performed through subjective modality which according to V. Vinogradov is the implicit subjective-evaluative attitude of the speaker/writer (Vinogradov 1950:725-731). Great is the number of studies, where repetition has been discussed on different linguistic levels. We will make an attempt to analyse it text level in Oscar Wilde's fairy tale "The Devoted Friend" thus trying to prove that textual repetition implies shades of ironic modality in the fairy tale.
\end{abstract}

Key words: textual repetition, modality, text linguistics, communicative context, impact.

\section{Introduction}

In the recent years linguists have been focusing on different aspects of linguistics and on different language levels. Text Linguistics focuses on semantic, stylistic, grammatical aspects. The sphere of text linguistics studying text as a complex of multilevel system displays its semantic, structural, functional unity.

Text linguistics is an interdisciplinary and multidisciplinary sphere which deals with texts as a communication system, as a complex of multi-level system bearing semantic, structural and functional unity. It keeps in its focus problems that have traditionally been semantic, stylistic and grammatical. Different linguists comment on textual parameters differently. Some of them single out verbal, syntactic, semantic parameters 
as a basic means to make up a text. Others point out topic, focus and linkage as the main content of the text. I. Galperin mentions the following textual categories: informativeness, completeness, integrity, cohesion, retrospection, prospection, presupposition, continuum, depth and pragmatics (found in Galperin 1981:11). Unlike a spontaneous speech, text is a result of integrity and wholeness comprised by different types of linkage - lexical, grammatical, logical and stylistic. Text is organized at a higher level than that of the sentence with the six segmental levels of language phonemic, morphemic, lexemic, phrasemic, proposemic, supra-proposemic. Application of repetition is also an important characteristic of a text. This particular study gives us a wide diapason to ascertain that repetitions on text level used by O. Wilde imply shades of comical meaning in general and shades of ironical meaning in particular.

\section{O. Wilde: A Master of Irony through Repetition}

The present article is devoted to the study of irony through repetition on the level of text which presupposes negative evaluative overtones in Wilde's tales.

Oscar Wilde's tales are partly for children, and partly for those who have kept the childlike facility of wonder and joy, and who find in simplicity a subtle strangeness. Being one of the prominent Victorian aesthetes, O. Wilde opens the gates of priceless values and touches upon the highest material things and discusses them in his tales. Making his writing highly wrought, he doesn't necessarily picture only the best or the worst sides of life, he doesn't aim at being either an optimist or a pessimist. Neither evil nor good are leading at the end of his tales. The gist of his writings is the process, procedure, the moderate gradation of the plot. Among other tropes and figures (metaphors, similes, epithets, personifications) he quite often uses repetitions to make his speech audible and available for every reader.

Repetition may be referred to the past and present. Even in ancient times many philosophers used the power of repetition in their rhetorical speeches to make the letter clearer, more emphatic and enhancing. In "Poetics" Aristotle redeems the power of repetition as a figure of speech which purposefully strays from everyday norm and gives essence to the elevated style (found in Ross 1959:9). He points the recurrence of syntactic structures which creates parallels.

The power of repetition often demonstrates the desire of the author to make his speech more eye-catching, as it is obviously shown in the following passage:

\section{"Be happy", cried the Nightingale, "be happy, you shall have your red rose."

$$
\text { (O. Wilde "Fairy Tales", p. 42) }
$$

The use of figurative language often becomes a need. It is not only stylistically appealing but it also helps to convey the message in a much more engaging and notable 
way. The atmosphere created by the usage of repetition cannot be achieved through any other device. It has the ability of making a simple sentence sound dramatic and emphatic. The same thing can be observed in the scope of a text. It enhances the beauty of a sentence and stresses the point of main significance. The beauty of reading a piece of prose or poetry with abundant repetitions in it is the balance where we, as readers, have to decipher appropriate associations and understand the underlying/coded meanings.

Repetition as a literary term can be used both constructively and destructively. The constructive usage encompasses functions such as putting emphasis on a point, confirming a fact or an idea, cohesion, mimesis, transition, showing impartiality and/or describing a notion. The same literary device when used destructively can disintegrate the entire piece of writing.

Repetition is also one of the devices belonging to emotive language when being applied to the logical language becomes simply an instrument of grammar. Its origin is to be seen in the excitement accompanying the expression of a feeling being brought to its highest tension. In the above example, through the repetition of be happy the excited state of mind and a great desire to be helpful to the hero of the tale is depicted.

Repetition builds redundancy into a text. However, as a rhetorical device, repetition can be used for emphasis or reinforcement of a key idea. In fiction it may have three effects which all bear upon the nature of the text and of the author's desire to persuade and convince the reader that the chosen personages and the message he presents it correctly arranged. As a powerful tool, repetition is widely used in Wilde's tales.

According to I. Galperin there are several kinds of repetition (found in Galperin 1977:211) which are classified according to compositional patterns.

- The repeated word comes at the beginning - anaphora

- The repeated word comes in the end-epiphora

- Logical function of repetition may be viewed as - the bachground

- Arranged in the form of a frame - framing

- The last word of the utterance in the beginning of the other-anadiploses

- The linking device used several times in one utterance - chain repetition

In the text we have analyzed namely in O.Wilde's "Devoted Friend" most frequently chain repetitions are used to show the real nature of personages, their way of perceiving the objective world, their outlook and mentality.

The cases of irony expressed through repetition in the context of Wilde's fairy tale. "The Devoted Friend" are numerous. In this well-known tale the author depicts two heroes, two contrary personages, two "friends" - Little Hans and the Miller. Little Hans was very poor, kind-hearted and a devoted friend to his "best friend" Miller. Hans was so poor that he suffered a good deal in winter as he had no fruit or flowers to take to the market to sell and he often had to go to bed without any supper. Rich and prosperous Miller turned to be poor Hans' "best friend". 
He would never go by Hans' garden without leaning over the wall and plucking a large nosegay or a handful of sweet herbs, or filling his pockets with plums and cherries if it was fruit season.

$$
\text { (O. Wilde "Fairy Tales", p. 55) }
$$

In the passage the author implicitly shows his negative attitude towards the Miller, in spite of the fact that at first sight the Miller endeavors to show his "devotedness".

In the following passage again the author doesn't lose the chance to remind the reader of the Miller's "best quality to be a devoted friend", as he always tries to make little Hans do a favor for him, assuring that he is going to give little Hans his wheelbarrow - a thing which he himself doesn't need at all and doesn't know what to do with. Both passages outline the presupposed negative, connotative overtones of irony through repetition:

Hans, said the Miller, I will give you my wheelbarrow. It is not in very good repair; indeed, one side is gone, and there is something wrong with the wheel spokes; but in spite of that I will give it to you. I know it is very generous of me, and great many people would think me extremely foolish for parting with it; but I am not like the rest of the world. I think that generosity is the essence of friendship, and, besides, I have got a new wheelbarrow for myself. Yes, you will set your mind as ease, I will give you my wheelbarrow.

$$
\text { (O. Wilde "Fairy Tales", p.61) }
$$

Here by means of repetition the author explicitly depicts his negative, ironical attitude towards the Miller.

In the next passage the author describes how the Miller comes down to get the money for his sack of flour and sees that little Hans is in bed. Again, he assures Hans that the latter is very lazy.

"Upon my word," - said the Miller, - "you are very lazy. Really considering that I am, going to give you my wheelbarrow I think you might work harder. Idleness is a great sin, and I don't like any of my friends to be idle or sluggish."

(O. Wilde "Fairy Tales", p.62)

The coming day wouldn't bring anything hopeful for Hans as again he willingly or not had to do something for his "best" friend - to carry the sack of flour to the market. 
Oh, I am sorry, said Hans but I am really very busy today. I have got all my creepers to nail up, and flowers to water, and all my grass to roll.

Well, really, as I am going to give you my wheelbarrow, it's rather unfriendly of you to refuse.

(O. Wilde "Fairy Tales", p.62)

Do you think it's rather unfriendly of me to say I was busy $\times$ he inquired in a shy and timid voice.

Well, really, answered the Miller, I don't think it is much to ask of you, considering that I am going to give you my wheelbarrow; but of course, if you refuse I will go and do it myself.

(O. Wilde "Fairy Tales", p.63)

Here again the Miller tries to make a negative psychological impact on his poor friend threatening that if the latter doesn't have any intention to get down to business he will do it himself.

Again in the next passage the Miller comes to visit Hans, pleading him to go for the doctor as his son has fallen off the ladder and it is too far for him to go and ask the doctor to come, and he doesn't lose the chance to remind him about the "expected" present. Certainly Hans agrees and does whatever his "best friend" asks.

Dear Hans the doctor lives far away and it is such a bad night, that it has just occurred to me that it would be much better if you went instead of me. You know, am going to give you my wheelbarrow so it is fair that you should do something for me in return.

(O. Wilde "Fairy Tales", p.64)

From the passage above it is quite obvious that the author depicts his personage Miller who never fails a chance to abuse his rank and position over his best friend in the shade of ironical light.

In all the above mentioned cases it is clear that the choice of the tense forms in which the utterance is presented is not accidental. The author prefers either the future indefinite or the present continuous tenses, and indicative mood which definitely show only the nearest intentions of the planned action and not the result of the action. This refers to the action of giving the wheelbarrow to little Hans, where the Miller always uses I will give or I am going to give constructions. Returning from the doctor, Hans is lost on the moors in the storm and drowns in a pool of water. After Hans's funeral, the miller's only emotion is regret as he has been unable to dispose of the wheelbarrow

Only in the last passage the author puts his final mark on the characteristics of the main hero - the Miller who mourns the death of his best friend. Hans died that terrible 
night because of the horrible storm, when he was sent for the doctor for the sake of Miller's son.

A great loss to me at any rate, said the Miller, why I had as good as given him my wheelbarrow, and now I really don't know what to do with it. It is very much in my way at home and it is in such bad repair, that I could not get anything for it if I sold it. I will certainly take care not to give away anything again. One certainly suffers from being generous.

(O. Wilde "Fairy Tales", p.65)

\section{Conclusion}

The analysis of repetition on the text level, in Oscar Wilde's tales, allows us to conclude that in the above-mentioned contexts which make up the whole text of Wilde's tale "The Devoted Friend", irony is manifested and realized through textual repetition. Evidently, there is a certain non-correspondence between "plane of content" and "plane of meaning".

Secondly, the study enables us to draw a conclusion that textual repetition very often may express negative-evaluative overtones or connotations, realized by means of irony. Irony in comparison with humor implies non-correspondence between "plane of context" and "plane of expression", whereas in the case of humor the "plane of context" and the "plane of expression" undoubtedly coincide.

\section{References:}

1. Galperin, I. (1981) Tekst kak obyekt lingvisticheskogo issledovaniya. M.: MGU.

2. Galperin, I (1977) Stylistics: M.: "Higher School”.

3. Halliday, M.; Hassan, R. (1976) Cohesion in English. London.

4. Halliday, M.A.K. (1977) Text as a Semantic Unit Choice in Social Contexts. // Grammars and Descriptions (research in text theory 1). / Ed. by T.A. Dijk and Petofi. Berlin and N.Y.

5. Mkhitaryan, Ye.; Chubaryan, À. (2011) Theoretical English Grammar. Yerevan: YSU Press.

6. Ross, W.D. (Ed.) (1959) Art Rhetorica. Oxford: OUP.

7. Vinogradov, V. (1950) O kategorii modalnosti I modalnikh slov. M.: Nauka. 


\section{Source of Data:}

Wilde, O. (1970) Fairy Tales. M.: Progress.

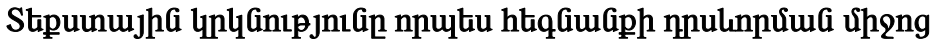

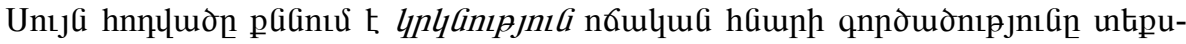

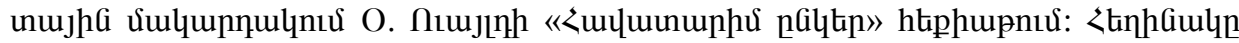

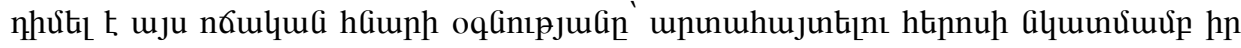

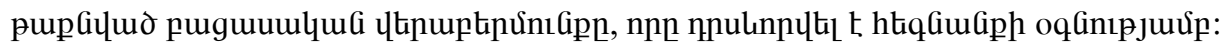

\section{Текстовый повтор как проявление иронии}

В данной статье рассматривается повтор как стилистическое выразительное средство на уровне текста в сказке О. Уальда “Преданный Друг”. Рассматриваемый материал дает основу предположить, что при помощи иронического повтора текст обретает негативную оценочную модальность. 